\title{
DESIGN AND EVALUATION OF CRUSHING HAMMER MILL
}

\author{
M. M. IBRAHIM ${ }^{(1)}$, M. S. OMRAN ${ }^{(1)}$ and E. N. ABD ELRHMAN ${ }^{(2)}$
}

\section{ABSTRACT}

A grain size reduction hammer mill for crushing corn (Zea mays L.) was designed depending on variety characteristics and by using computer aided design "ANSYS" software. Suitability of fabricated hammer was tested at three levels of hammer rotor speeds $\left(R_{S}\right)(600,1000$ and 1440 rpm), three levels of screen holes diameter $\left(S_{d}\right)(2,4$ and $6 \mathrm{~mm})$ and three levels of feeding rates $\left(F_{R}\right)\left(60,90\right.$ and $\left.120 \mathrm{~kg} \mathrm{~h}^{-1}\right)$. Geometric mean diameter of crushed corn $(d g w)$, machine productivity $\left(P_{m}\right)$, consumed energy $(C E)$ and cost $\left(C_{O}\right)$ were evaluation criteria. Results indicated that the highest $\left(P_{m}\right)\left(113 \mathrm{~kg} \mathrm{~h}^{-1}\right)$ and lowest $\left(C E\right.$ and $\left.C_{O}\right)$ were at $1440 \mathrm{rpm}$ $\left(R_{S}\right), 6 \mathrm{~mm}\left(S_{d}\right)$ and $120 \mathrm{~kg} \mathrm{~h}^{-1}\left(F_{R}\right)$. The empirical results obtained from experiments were used to introduce a derived mathematical equation to predict the value of "dgw, $P_{m}, C E$ and $C_{O}$ " as a function of " $R_{S}, F_{R}$ and $S_{d}^{\prime \prime}$.

Keywords: Hammer mill, design, grinding, crushing, maize, consumed energy.

\section{INTRODUCTION}

$\mathrm{M}$ aize or corn (Zea mays L.) yearly cultivated area in Egypt was 2.192 million feddans. According to Annual Statistics (FAO, 2017), the total yearly production of maize 7.1 million tonnes

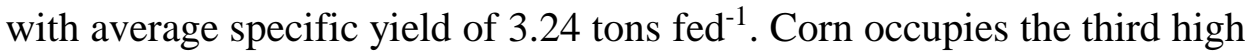
priority among the leading cereal crops after wheat and rice (Verheye, 2010 and Zohry et al., 2016). The amount of imported corn was about 10805.6 million tons in 2014 (Abd ElFatah et al., 2015). Maize is consumed directly by humans, animal feed, poultry diets with uniform nutritive value, corn starch, corn syrup, oil, protein, as a coproduct as anthocyanins which used as naturally sourced colors in food and cosmetics, alcoholic beverages, and recently as biofuels (Pérez-Bonilla et al., 2014; Dabbour et al., 2015 and Herrera et al., 2018).

(1) Assoc. Prof., Agric. Eng. Dept., Fac. of Agric., Cairo Univ.

(2) Assist. Prof., Agric. Eng. Dept., Fac. of Agric., Cairo Univ. 
Islam et al. (2015) mentioned that around 60\% corn is used in poultry feed as a feed ingredient. Feed quality and appearance is directly related to the corn moisture which had a direct effect on storage time.The most studies focusing on optimal grain size, specifically corn particle size, showed that smaller corn particle size has a greater surface area to volume ratio (Parsons et al., 2006). In addition, grain size reduction is affected by several criteria, such as grain hardness, toughness, initial particle size, moisture content, softening temperature, purity required, physiological effect, feeding rate and machine operating variables (Mani et al., 2004 and Tumuluru et al., 2014). Moreover, both compression and shear forces were involved in size reduction of granular grains (Berk, 2018). Therefore, reduction mills equipment were classified according to main action exerted on the processed material as impact, pressure, attrition, and shearing milling. Total specific energy of switchgrass, wheat straw, and corn stover increased by 37, 30 and 45\%, respectively, with an increase in hammer mill speed from 2000 to $3600 \mathrm{rpm}$ (Bitra et al., 2009). El Shal et al. (2010) mentioned that the proper conditions for operating the hammer mill used to produce pelleting feed were drum speed of $2250 \mathrm{rpm}$ (33.56 $\mathrm{m} / \mathrm{s})$, grain moisture content $(10 \%)$, concave clearance $(5 \mathrm{~mm})$ and hammer thickness (5 mm). Wotosiewicz-Glab et al. (2017) fabricated a fully automated laboratory hummer milling device worked by generated rotating electromagnetic field as an energy source. A significance relation was found between rice flour physiochemical and gelatinization properties and dry or wet milling process (Leewatchararongjaroen and Anuntagool, 2016). Milling area is defined by collision energy where wear of particles occurs in the upper half of milling chamber. A direct correlation between high milling speeds and collision energy, energy efficiency and accelerated wear of rice were observed (Han et al., 2016). A vibratory mill was developed depending on theory of angular oscillations, characterized by five degrees of freedom at $1500 \mathrm{rpm}$ and $0.75 \mathrm{~kW}$ power for grinding maize, peas, rye and wheat at moisture content 8 - 11\%. Grinding efficiency was evaluated by determining specific area, $\mathrm{m}^{2}$, and particle size distribution, $\mu \mathrm{m}$, at angular velocity of the drive shaft $110 \mathrm{rad} \mathrm{s}^{-1}$. It was possible to produce a material with a specific surface of $5000 \mathrm{~cm}^{2} \mathrm{~g}^{-1}$ at rate of $220 \mathrm{~kg} \mathrm{~h}^{-1}$ and specific energy 
consumption of $0.003 \mathrm{~kW} \mathrm{~h} \mathrm{~kg}{ }^{-1}$ (Bulgakov et al., 2018). It was found that as feed rates increases the power requirements of the grinding operation increased while it decreased with increasing screen opening size (Yousf, 2005). The objective of the present work is to design, fabricate and evaluate low-cost hammer mill during crushing grains and besting its performance with geometric mean diameter of crushed grain, machine productivity, consumed energy and cost.

\section{MATERIALS AND METHODS}

\subsection{Physical and mechanical properties of corn kernel}

\subsubsection{Physical properties}

Physical properties of the corn (SC- 168 variety) kernels were obtained at moisture content $12.34 \%$ w.b. Some physical properties of corn kernels that are related to the crushing process were measured using SmartGrain Phenotyping Software developed by Tanabata et al. (2012), a scanned image contains (100 kernel) with three replicates were analysed. Projection area size; $\mathrm{mm}^{2}$, perimeter length; $\mathrm{mm}$, length; $\mathrm{mm}$, width; $\mathrm{mm}$, roundness, length to width ratio and distance between intersection of length and width (IS) and center of gravity (CG) were calculated at scale $0.0869 \mathrm{~mm} \mathrm{pixel}^{-1}$. The kernel thickness was measured with calliper and bulk density was determined using the standard test weight procedure method.

\subsubsection{Compression test}

The parallel-plate compressive test was carried out to determine the mechanical properties using a universal testing machine (Instron - 1000 $\mathrm{N}$ ). Individual corn kernel was uniaxilly compressed at a cross-head speed of $5 \mathrm{~mm} \mathrm{~min}{ }^{-1}$ to a total deformation $10 \mathrm{~mm}$. A plate (diameter $7.5 \mathrm{~cm}$ ) compressed a corn kernel slab placed on a mounted fixed table. A random 10 corn kernel were taken for compression tests. The test was done on three axes which are the major axis, the minor axis and the intermediate axis. The dimension of each axis was determined before starting the test (Fig. 1).

A typical force-deformation curve is shown in Fig. (2). The forcedeformation curve exhibited two peak points. The first peak corresponds 
to the yield point at which kernel damage was initiated. The second peak corresponds to the maximum compressive force.
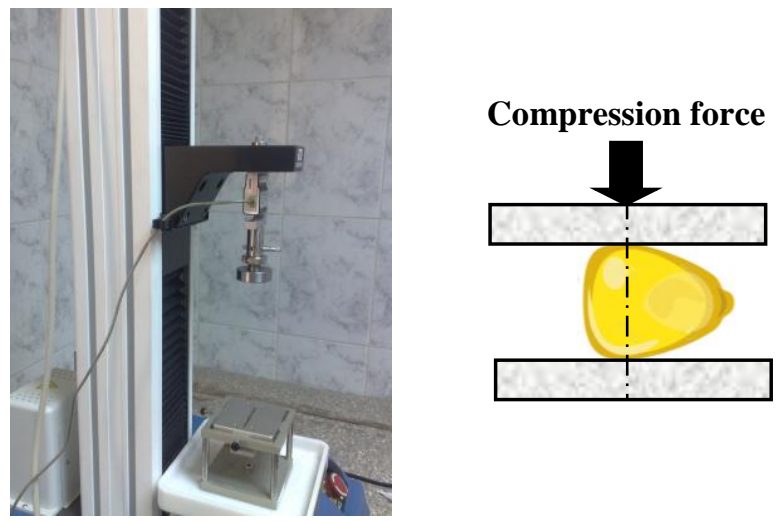

Fig. (1): Corn kernel loaded between the two parallel plates by universal testing machine.

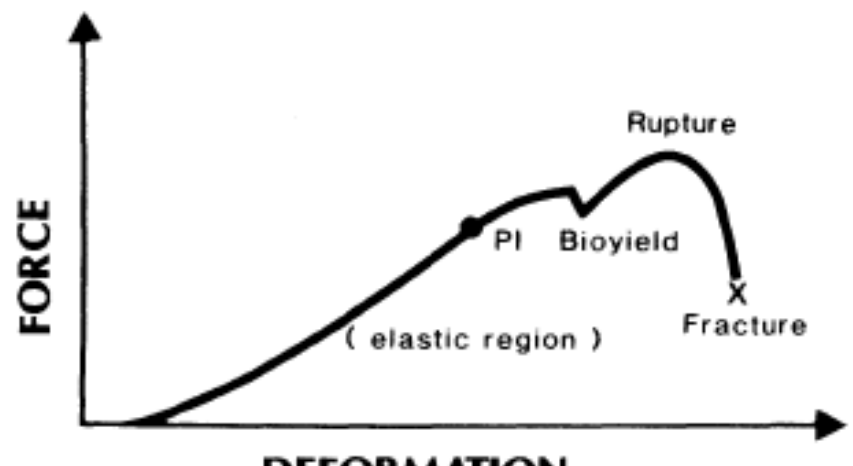

DEFORMATION

Fig. (2): A Typical force-deformation curve for agricultural materials.

Rupture energy (RE) or work required for rupture was determined by calculating the area under the force-deformation curve from the following equation (Soyoye et al., 2018):

$$
\mathrm{RE}=\frac{\mathrm{F}_{\mathrm{r}} \mathrm{D}_{\mathrm{r}}}{2}
$$

Where

Fr : Rupture force, N.

Dr : Deformation at rupture point, $\mathrm{m}$. 
It was calculated specific rupture energy $\left(\mathrm{J} \mathrm{kg}^{-1}\right)=\mathrm{RE} / \mathrm{m}$, where $\mathrm{m}$ is the mass of the tested kernel $(\mathrm{kg})$.

\subsection{Design of machine components}

Some parameters were considered in the design of some parts of the machine: easy of operation, economy to make the machine affordable and within the capacity of the local farmers, using standard component and local available material. The designed machine shown in Fig. (3) consisted of the following units:

\subsubsection{Feeding unit}

The major parameter governing the size and configuration of the feed hopper is the throughput capacity of the machine. The hopper must be able to accommodate enough corn kernels to achieve the desired throughput capacity. Feeding unit was pyramidal in shape and made by plate steel $2 \mathrm{~mm}$ thick. The hopper dimensions are $20 \mathrm{x} 20 \mathrm{~cm}$ top opening, $10 \times 10 \mathrm{~cm}$ base opening and $25 \mathrm{~cm}$ height. The plate was marked and cut to sizes and then welded together.

\subsubsection{Frame and support}

The frame was manufactured from steel structures of angle-cross section (L $40 \mathrm{~mm} \times 40 \mathrm{~mm} \times 4 \mathrm{~mm}$ ). The dimensions of the frame are $120 \mathrm{~cm}$ length, $65 \mathrm{~cm}$ width, and $80 \mathrm{~cm}$ height. The frame includes two parts first part for supporting the motor and second part for supporting the hammer mill.

\subsubsection{Power transmission unit}

Pulley size: V-belt was used because it is mostly common used, where a great amount of power is to be transmitted from one pulley to another, according to Khurmi and Gupta (2005):

$$
\mathrm{N}_{1} \mathrm{D}_{1}=\mathrm{N}_{2} \mathrm{D}_{2}
$$

Where

$\mathrm{N}_{1}, \mathrm{~N}_{2} \quad$ : Speed of driving and driven pulley respectively, rpm.

$\mathrm{D}_{1}, \mathrm{D}_{2} \quad$ : Diameter of driving and driven pulley respectively, $\mathrm{mm}$.

The machine will operate at three speeds: 600 (6.8), 1000 (11.3) and 1440 (16.3) $\mathrm{rpm}\left(\mathrm{m} \mathrm{s}^{-1}\right)$. So, Substituting the required speeds at the mill unit 
$\left(\mathrm{N}_{1}\right.$ are 600,1000 and $1440 \mathrm{rpm}$, the rated speed of the electric motor $\mathrm{N}_{2}$ was $1440 \mathrm{rpm}), \mathrm{D}_{1}$ and $\mathrm{D}_{2}$ where calculated as given in the table (1).

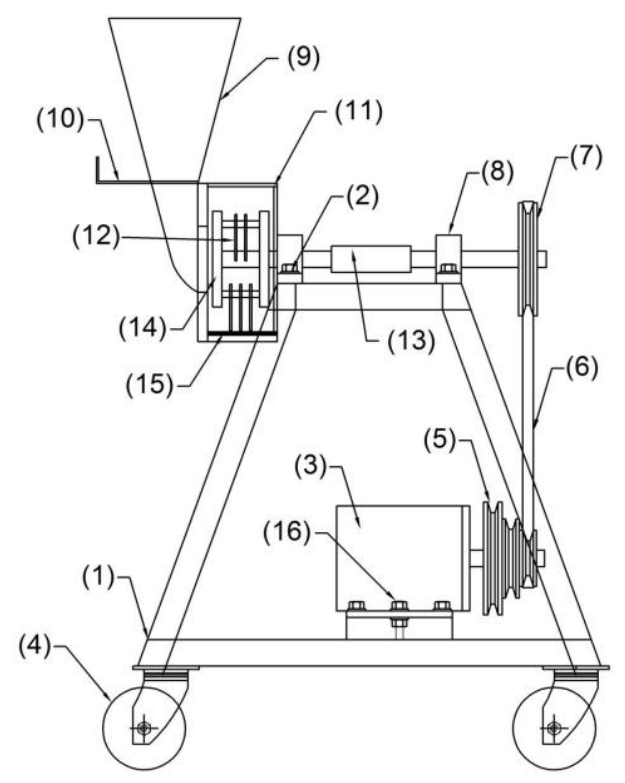

1 Machine base

2 Bolts and nut M10

3 Motor

4 Rotary caster single bearing wheel

5 Multi-pulleys block

$6 \quad$-belt $=16 \mathrm{~mm}$

7 Single-pulleys block

8 Bearing housing UCP205-100
9 Feed hopper

10 Control gate

11 Hammer chamber

12 Hammers

13 Main shaft

14 Hammer arm

15 Screen

16 Belt stretcher

Fig. (3): Diagrammatic sketch of the hammer mill.

Table (1): Values of $D_{1}$ and $D_{2}$ for driving and driven pulley.

\begin{tabular}{lcccccc}
\hline & $\begin{array}{c}\text { Rotor velocity } \\
\left(\mathrm{m} \mathrm{sec}^{-1}\right)\end{array}$ & \multicolumn{2}{c}{ Pulley of machine } & & \multicolumn{2}{c}{ Pulley of motor } \\
\cline { 3 - 4 } \cline { 6 - 7 } & $\mathrm{N}_{1}(\mathrm{rpm})$ & $\mathrm{D}_{1}(\mathrm{~mm})$ & & $\mathrm{N}_{2}(\mathrm{rpm})$ & $\mathrm{D}_{2}(\mathrm{~mm})$ \\
\hline $1 \mathrm{st}$ & 6.8 & 600 & 140 & & 1440 & 58 \\
$2 \mathrm{nd}$ & 11.3 & 1000 & 140 & & 1440 & 97 \\
$3 \mathrm{rd}$ & 16.3 & 1440 & 140 & & 1440 & 140 \\
\hline
\end{tabular}


Length of belt $(\mathbf{L})$ : The length of the belt was calculated from the following equation (Khurmi and Gupta, 2005):

$$
L=\frac{\pi}{2}\left(D_{1}+D_{2}\right)+2 x+\frac{\left(D_{1}-D_{2}\right)^{2}}{4 x}
$$

Where

X : Distance between centres of the two pulleys $(=40 \mathrm{~cm})$.

So, the maximum belt length (L) is $1.2 \mathrm{~m}$.

\subsubsection{Milling unit}

Hammer mill operates on the impact principles and crushing. The hammer mill consists of a number of hammers put into radical position on rotor shaft which rotates in a thick steel housing. The material is fed into the mill unit from a hopper; the hammers strike the material with great force and pulverize it. At a surface on the bottom of the housing and close to the tip of the hammers is a screen. The crushing materials in the form of ground particles pass through the screen.

\section{Kinetics of hammer rotation}

The basic assumptions of the hammer rotate were (Fig. 4):

1. Rotor hammer mass is greater than mass of single particles of corn kernel.

2. Before impact, linear velocity of the crushing bar is much more important than the particle velocity of corn kernel, so kinetic energy of particles is negligible.

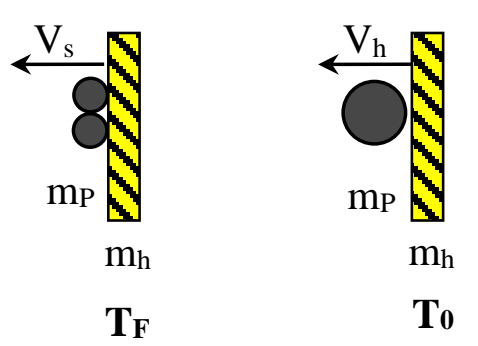

After impact Before impact

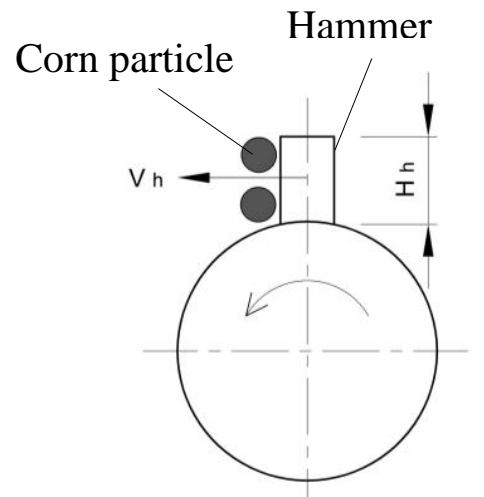

Fig. (4): Mechanism of crushing by impact in a hammer crusher 
The crushing effect depend on kinetic energy of hammer, this depends on the interchange of energy between hammer and particle or the loss of energy due to impact. Based on dynamics of non-elastic collision and the conservation of linear momentum before and after the impact, it can get the following equation:

$$
m_{\mathrm{h}} \mathrm{V}_{\mathrm{h}}=\left(\mathrm{m}_{\mathrm{h}}+\mathrm{m}_{\mathrm{p}}\right) \mathrm{V}_{\mathrm{S}}
$$

Initial kinetic energy $\left(\mathrm{T}_{0}\right)$ of the system before impact is,

$$
\mathrm{T}_{0}=1 / 2 \mathrm{~m}_{\mathrm{h}} \mathrm{V}_{\mathrm{h}}^{2}
$$

Where

$\mathrm{m}_{\mathrm{h}} \quad$ : Mass of one hammer $(=\mathbf{4 9 . 5 2} \mathrm{g})$.

$\mathrm{m}_{\mathrm{p}}$ : Mass of corn particle.

$\mathrm{V}_{\mathrm{h}} \quad$ : Velocity of hammer $\left(6.8,11.3\right.$ and $\left.16.3 \mathrm{~m} \mathrm{~s}^{-1}\right)$.

$\mathrm{V}_{\mathrm{S}}$ : System velocity (hammer + crushed corn particles) at the end of impact.

Final kinetic energy $\left(\mathrm{T}_{\mathrm{F}}\right)$ of the system is give by the following equation:

$$
\mathrm{T}_{\mathrm{F}}=1 / 2\left(\mathrm{~m}_{\mathrm{h}}+\mathrm{m}_{\mathrm{p}}\right) \mathrm{V}_{\mathrm{s}}^{2}
$$

It can write $\left(\mathrm{T}_{\mathrm{F}}\right)$ as follows:

$$
T_{F}=\frac{m_{h}^{2} V_{h}^{2}}{2\left(m_{h}+m_{p}\right)}
$$

The amount of kinetic energy lost due to crushing impact $\left(\mathrm{T}_{\mathrm{C}}\right)$ is given by the following equation:

$$
\mathrm{T}_{\mathrm{C}}=T_{F}-T_{0}=\left(\frac{m_{h}{ }^{2} V_{h}^{2}}{2}\right)\left(\frac{m_{h}{ }^{2}}{\left(m_{h}+m_{p}\right)}\right)
$$

Where, the kinetic energy of particles is negligible, so $\mathrm{T}_{\mathrm{F}}=\mathrm{T}_{0}=1 / 2 \mathrm{~m}_{\mathrm{h}} \mathrm{V}_{\mathrm{h}}^{2}$ By applying the previous equation, the kinetic energy of one hammer ranges from 1.14 to 6.58 joule ( $\mathrm{V}_{\mathrm{h}}$ ranges from 6.8 to $16.3 \mathrm{~m} \mathrm{~s}^{-1}$ ).

The total mass of the number of corn particles that impacted with one hammer at simultaneously $=\mathrm{m}_{\mathrm{p}} \times$ hammer height $\left(\mathrm{H}_{\mathrm{h}}\right) /$ width of corn kernel $=0.353 \mathrm{~g} \times 70 \mathrm{~mm} / 8.76 \mathrm{~mm}=\mathbf{2 . 8 2} \mathrm{g}$. The specific energy of the one hammer to rupture the corn ranges from 405.99 to $2332.80 \mathrm{~J} \mathrm{~kg}^{-1}$. By comparing the previous result with rupture energy computed from the force deformation curve $(\mathrm{RE} / \mathrm{m})$ in table (5), the specific kinetic energy of the one hammer should be much higher than specific kinetic energy associated to corn particles (RE/m). 


\section{The exerted centrifugal force by the hammer}

Centrifugal force of the hammers can be calculated by following equation (Hannah and Stephens, 2004):

$$
F_{h}=\frac{m_{h} v_{h}^{2}}{r_{h}}=N_{h} \mathrm{~m}_{\mathrm{h}} \mathrm{r}_{\mathrm{h}} \omega_{h}^{2}
$$

Where

$\mathrm{F}_{\mathrm{h}} \quad$ : Centrifugal force, $\mathrm{N}$.

$\mathrm{N}_{\mathrm{h}}:$ Number of hammers $=10$.

$\mathrm{m}_{\mathrm{h}} \quad$ : Hammer mass, $\mathrm{kg}$.

$r_{h} \quad: \quad$ Radius of hammer, $m=0.053$.

$\omega_{\mathrm{h}} \quad:$ Angular velocity of hammer, $\left(=150.72 \mathrm{red} \mathrm{sec}^{-1}\right)=\frac{2 \pi r \mathrm{~N}}{60}$.

$\mathrm{N}$ : Velocity of the hammer $=1440 \mathrm{rpm}$.

For the hammer $\quad$ Mass $\left(\mathrm{m}_{\mathrm{h}}\right)=\rho \times \mathrm{Vc}$

Where

$\rho \quad$ : Density of the material (for steel $=7860 \mathrm{~kg} \mathrm{~m}^{-3}$ ).

$\mathrm{V}_{\mathrm{C}} \quad$ : Volume of the hammer (dimensions $7 \mathrm{~cm} \times 3 \mathrm{~cm} \times 0.3 \mathrm{~cm}$ ).

Each hammer was drilled at the bottom (hole of $10 \mathrm{~mm}$ ), to enable to be put it into position on the hammer shaft.

Mass of each hammer $=\mathbf{4 9 . 5 2} \mathrm{g}$, number of hammers 10 , so the centrifugal force exerted by the hammer $=\mathbf{5 9 6 . 2 1} \mathrm{N}$ (upward).

\subsubsection{Main shaft}

In order to transfer the power to the main shaft of the hammer mill, the various members (such as pulleys, and bearings) are mounted on it. The design of shaft is based on combined shock and fatigue, bending and torsional moment (Fig. 6). The diameter of the main shaft was calculated as following (Eric, 1976):

$$
d^{3}=\frac{16}{\pi S_{s}} \sqrt{\left[K_{b} M_{b}\right]^{2}+\left[K_{t} M_{t}\right]^{2}}
$$

Where

d : Diameter of shaft, $m$.

$\mathrm{M}_{\mathrm{b}} \quad$ : Resultant bending moment, $\mathrm{N}-\mathrm{m}$.

$\mathrm{M}_{\mathrm{t}} \quad$ : Torsional moment, $\mathrm{N}-\mathrm{m}$. 
$\mathrm{K}_{\mathrm{b}} \quad$ : Combined shock and fatigue factor applied to bending moment.

$\mathrm{K}_{\mathrm{t}} \quad$ : Combined shock and fatigue factor applied to torsional moment.

Ss : Allowable shear stress of the shaft material, $\mathrm{MN}-\mathrm{m}^{-2}$.

The values of $\mathrm{K}_{\mathrm{b}}$ and $\mathrm{K}_{\mathrm{t}}$ were taken as 1.5 and 1.0 respectively for the gradually applied load on the rotating shaft and the allowable shear stress of the shaft (Ss) as $40 \mathrm{MN}-\mathrm{m}^{-2}$ based on American Society of Mechanical Engineers (ASME).

$\mathrm{M}_{\mathrm{b}}$ was calculated by analyzing moments due to vertical loading in bending moment diagrams of the shaft. $\mathrm{M}_{\mathrm{t}}$ was calculated by the following equation:

$$
M_{t}=\frac{P \times 60}{2 \pi N}
$$

Where

$\mathrm{P}$ : Transmitted power, W.

Using $\mathrm{P}=750 \mathrm{~W}$ and $\mathrm{N}=600 \mathrm{rpm}, \mathrm{M}_{\mathrm{t}}$ was calculated as $11.94 \mathrm{~N}-\mathrm{m}$.

\section{The maximum bending moment}

The overall loading system on the shaft is as shown in Fig. (6).

For the pulley:

$$
\text { Weight of pulley }\left(\mathrm{W}_{\mathrm{P}}\right)=\mathrm{V}_{\mathrm{p}} \times \rho_{\mathrm{p}} \times \mathrm{g}
$$

Where

$\mathrm{V}_{\mathrm{P}} \quad$ : Volume of the pulley, $\mathrm{m}^{3}(140 \mathrm{~mm}$ - diameter and $40 \mathrm{~mm}-$ thick)

$\rho_{\mathrm{p}} \quad$ : Density of the pulley material (for aluminium $=2700 \mathrm{~kg} \mathrm{~m}^{-3}$ ). So, weight of pulley $\left(\mathrm{W}_{\mathrm{p}}\right)=\mathbf{1 6 . 3} \mathrm{N}$.

According to ASTM Standards, the V-belt is $16 \mathrm{~mm}$ that can transmit 2 $15 \mathrm{~kW}$.

Belt Force: The power transmitted by a belt drive is a function of the belt tensions and belt speed. The belt tensioning forces on the pulley was calculated according to the following equations (Khurmi and Gupta, 2005).

$$
\begin{aligned}
& 2.3 \log \mathrm{T}_{1} / \mathrm{T}_{2}=\mu \theta \operatorname{cosec} \beta \\
& \mathrm{Mt}=\left(\mathrm{T}_{1}-\mathrm{T}_{2}\right) \mathrm{R}_{1}
\end{aligned}
$$


Where

$\mathrm{T}_{1} \quad$ : Belt tension in tight side, $\mathrm{N}$.

$\mathrm{T}_{2}$ : Belt tension in loose side, $\mathrm{N}$.

$\mu \quad$ : Coefficient of friction between belt and pulley $(\mu=0.25)$.

$\theta \quad$ : Belt wrap angle, radian $=(180-2 \alpha) \pi / 180$.

$\alpha \quad: \quad \sin \alpha=\frac{D_{1}-D_{2}}{2 x}$.

$\mathrm{x}$ : Distance between centres of the two pulleys $(=400 \mathrm{~mm})$.

$2 \beta$ : Groove angle of the pulley $\left(32^{\circ}\right)$.

Mt : Torsional moment, N-m.

$\mathrm{R}_{1} \quad$ : Radius of the machine pulley, $\mathrm{m}$.

Torque transmitted by the pulley $(\mathrm{Mt})=\mathbf{1 1 . 9 4} \mathrm{N}-\mathrm{m}$. From the previous equations, $\mathrm{T}_{1}$ and $\mathrm{T}_{2}$ were calculated and are given in table (2):

\section{Table (2): Values of belt tension in tight and loose sides.}

\begin{tabular}{cccccccc}
\hline $\begin{array}{c}\mathbf{D}_{1} \\
(\mathbf{m m})\end{array}$ & $\begin{array}{c}\mathbf{D}_{2} \\
(\mathbf{m m})\end{array}$ & $\begin{array}{c}\boldsymbol{\alpha} \\
(\mathbf{d e g r e e})\end{array}$ & $\begin{array}{c}\boldsymbol{\theta} \\
(\mathbf{r a d i a n})\end{array}$ & $\begin{array}{c}\mathbf{T}_{\mathbf{1}} \\
(\mathbf{N})\end{array}$ & $\begin{array}{c}\mathbf{T}_{\mathbf{2}} \\
(\mathbf{N})\end{array}$ & $\mathbf{T}_{\mathbf{1}} / \mathbf{T}_{\mathbf{2}}$ & $\begin{array}{c}\mathbf{T}_{1}+\mathbf{T}_{\mathbf{2}} \\
(\mathbf{N})\end{array}$ \\
\hline 140 & 58 & 5.86 & 2.94 & 183.31 & 12.74 & 14.39 & 196.05 \\
140 & 97 & 3.07 & 3.03 & 182.17 & 11.60 & 15.7 & 193.78 \\
140 & 140 & 0 & 3.14 & 181.04 & 10.46 & 17.3 & 191.50 \\
\hline
\end{tabular}

The maximum value of $\mathrm{T}_{1}+\mathrm{T}_{2}=196.05 \mathrm{~N}$, with $\mathrm{T}_{1}=\mathbf{1 8 3 . 3 1}$ and $\mathrm{T}_{2}=$ 12.74 N, it was taken in the calculations. So, total load acting on pulley $=$ $\mathrm{T}_{1}+\mathrm{T}_{2}+\mathrm{W}_{\mathrm{p}}=\mathbf{2 1 2 . 3 5} \mathbf{N}$.

Accordingly, the shaft is subjected to vertical loads of the values presented in table (3) and Fig. (6).

The centrifugal force exerted by the hammer $=\mathbf{5 9 6 . 2 1} \mathrm{N}$ (upward), so distributed vertical loading $=\mathbf{5 9 6 . 2 1} / 0.12$ (length loaded of the shaft) $=$ 4968.42 N-m $\mathrm{m}^{-1}$.

Table (3): Vertical loads on the main shaft.

\begin{tabular}{lcc}
\hline Type of load & At $(\mathbf{A})$ & At $(\mathbf{B})$ \\
\hline Vertical & $\mathbf{5 9 6 . 2 1} \mathbf{N}\left(\mathbf{4 9 6 8 . 4 2 ~} \mathbf{N - m ^ { - 1 } )}\right.$ & $\mathbf{2 1 2 . 3 5} \mathbf{N}$ \\
\hline The vertical load diagram is shown in Fig. $(6)$. Let $\mathrm{R}_{\mathrm{P}}$ and $\mathrm{R}_{\mathrm{Q}}$ represent the \\
reactions at bearings $\mathrm{P}$ and $\mathrm{Q}$ respectively for vertical loading. Taking \\
moments about $P, \quad \therefore \mathrm{R}_{\mathrm{Q}}=\mathbf{4 6 7 . 5 8} \mathrm{N} \quad \therefore \mathrm{R}_{\mathrm{P}}=\mathbf{8 5 1 . 4 4} \mathrm{N}$
\end{tabular}


Bending moment diagram (B.M.D): The Fig. (5) shows the free body diagram, to calculate the moment at $\mathrm{P}$.

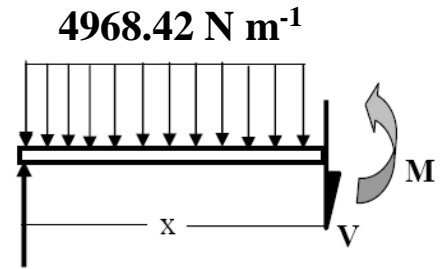

$596.21 \mathrm{~N}$

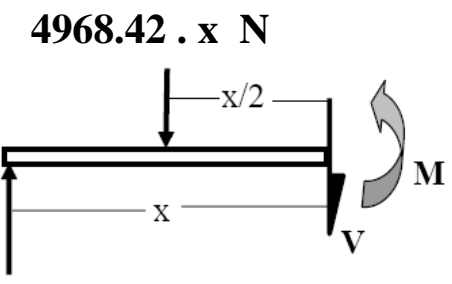

$596.21 \mathrm{~N}$

Fig. (5): Free body diagram for vertical load at point (A).

B.M. at $A, M_{\mathrm{P}}=4968.42 \times(0.12)^{2} / 2=\mathbf{3 5 . 7 7} \mathrm{N}-\mathrm{m}$

B.M. at $Q, M_{\mathrm{Q}}=596.21 \times 0.3-851.44 \times 0.24=\mathbf{- 2 5 . 4 8} \mathrm{N}-\mathrm{m}$

Fig. (6) shows the bending moment diagram for vertical loading. It is obvious that $P$ is the point of maximum bending moment.

Maximum bending moment $\left(\mathrm{M}_{\mathrm{b}}\right)$ was found to be $\mathbf{M}_{\mathbf{b}}=35.77 \mathrm{~N}-\mathbf{m}$. The maximum torque was found to be $\mathbf{M}_{\mathbf{t}}=\mathbf{1 1 . 9 4} \mathrm{N}-\mathrm{m}$.

By applying in the equation (11), shaft diameter of the main shaft (d) should be equal or more than $\mathbf{1 9 . 1 3} \mathrm{mm}=\mathbf{2 0} \mathrm{mm}$.

\subsubsection{Bearing selection}

The selection of a rolling bearing is made from a manufacturer's catalogue FAG rolling bearing catalogue was used to select the machine ball bearing.

\subsubsection{Electric motor}

Electric motor with single phase $(220 \mathrm{~V})$, power $1 \mathrm{hp}$ at $1440 \mathrm{rpm}$ was used as a power source for hammer mill.

\subsection{Finite element modeling}

The 3-D Finite Element modelling of the main shaft was designed by using ANSYS software (Version 14). The shaft is analyzed by ANSYS in three steps. First step involve meshing of the object and input material properties of shaft in software. 


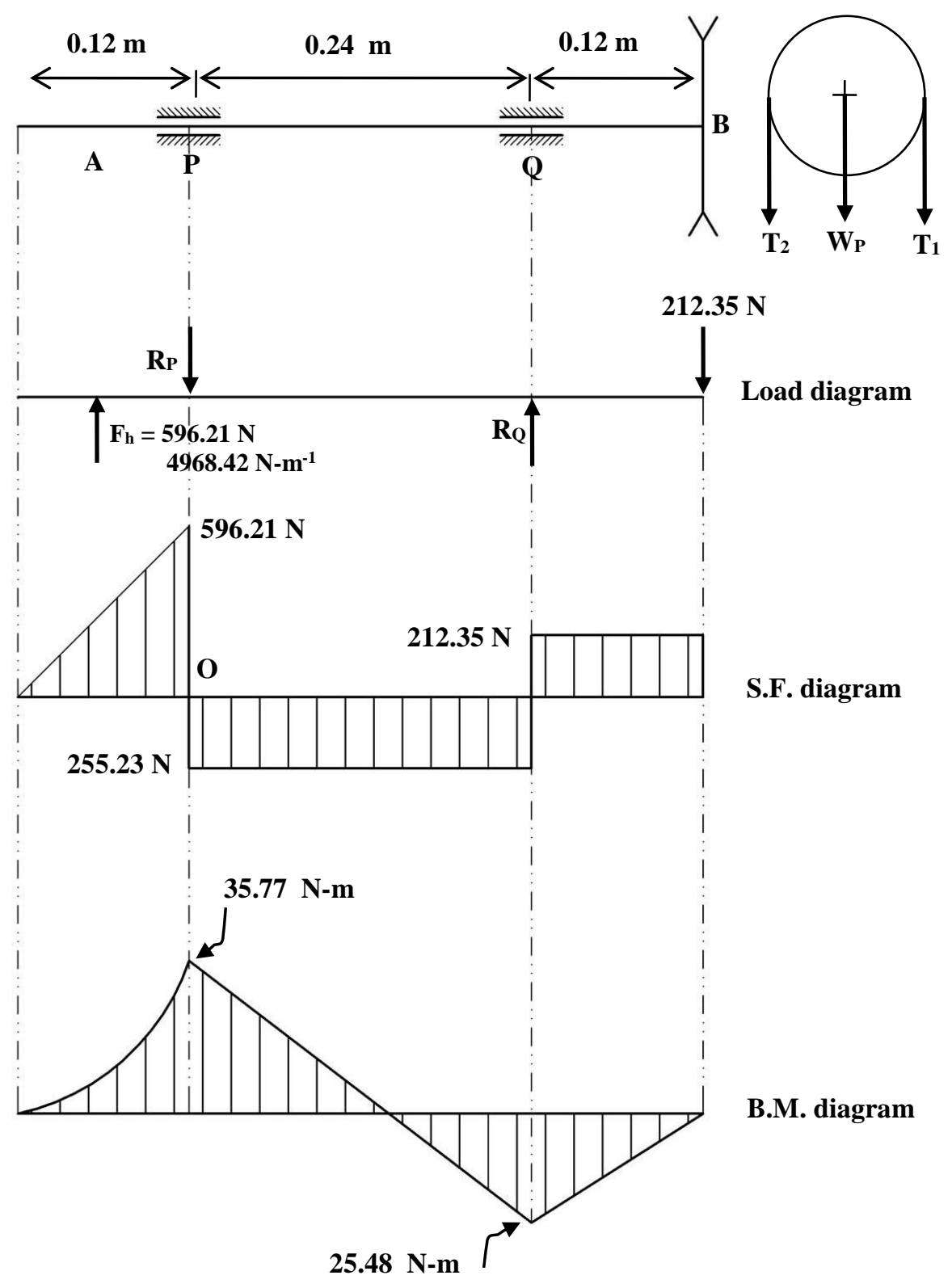

Fig. (6): The shearing and bending moment diagrams of the main shaft. The shaft had converted into 4127 elements and 7601 nodes. Second step involve selection of analysis type static and putting the boundary condition of loading and displacement in term of degree of freedom at the end occurring on shaft and then running the ANSYS software to get the 
analysed result in form of stress and deformation. The stress and deformation of the shaft observed after analysis is shown in Fig. (7). The maximum stress in shaft is $12.47 \mathrm{~N} \mathrm{~mm}^{-2}$ which is far less than the yield strength of the material $\left(45 \mathrm{~N} \mathrm{~mm}^{-2}\right)$. So, that shaft diameter is sufficient under these the current working conditions.

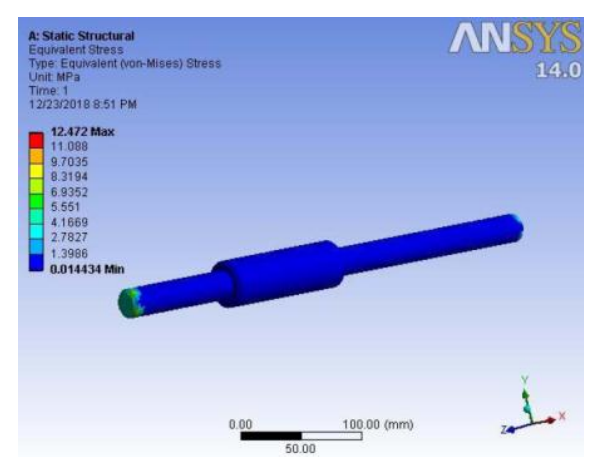

(a) Von Mises Stress

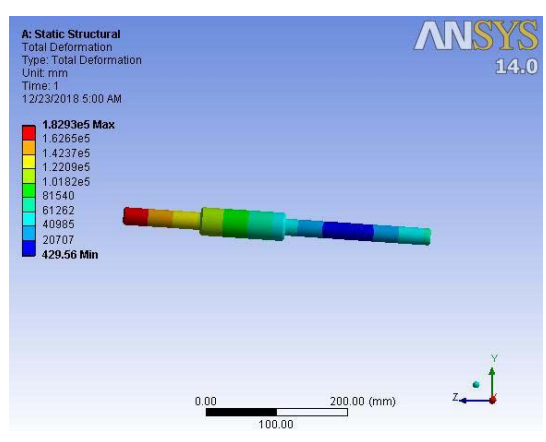

(b) Deformations

Fig. (7): Von Mises Stress and deformations of the rotor shaft in ANSYS.

\subsection{Performance evaluation}

The hammer mill was evaluated at three screen holes diameter, three levels of rotor speed and three feed rates. According to literature data (Srivastava et al., 2006; CIGR, 1999), in reference to this information, machine productivity, consumed energy and cost were evaluated at each combination of variables.

Table (4): Experimental plan for evaluating the machine.

\begin{tabular}{ll}
\hline \multicolumn{1}{c}{ Variables } & Levels \\
\hline Screen holes diameter $\left(\mathrm{S}_{\mathrm{d}}\right), \mathrm{mm}$ & $2,4,6$ \\
Hammer rotor speed $\left(\mathrm{R}_{\mathrm{s}}\right), \mathrm{rpm}\left(\mathrm{m} \mathrm{s}^{-1}\right)$ & $600(6.8), 1000(11.3), 1440(16.3)$ \\
Feeding rate $\left(\mathrm{F}_{\mathrm{R}}\right), \mathrm{kg} \mathrm{h}^{-1}$ & $60,90,120$ \\
\hline
\end{tabular}

Evaluation of the hammer mill was performed taking the following measuring parameters:

\subsubsection{Geometric mean diameter $\left(\mathrm{d}_{\mathrm{gw}}\right)$}

Particle size distribution of the ground corn after ground was determined according to ASABE Standard S319.3 by calculating geometric mean diameter (ASABE, 1999). About $100 \mathrm{~g}$ sample of 
grinds was placed on the top of a stack of sieves arranged from the largest to smallest opening. The duration of sieving was determined by $10 \mathrm{~min}$. After sieving, the mass retained on each sieve was weighed. The geometric mean diameter $\left(\mathrm{d}_{\mathrm{gw}}\right)$ of particle diameters for the sample were calculated according to the aforementioned standard using the following equation:

$$
d_{g w}=\log ^{-1}\left(\frac{\sum_{i=1}^{n}\left(W_{i} \log \overline{\mathrm{d}}_{\mathrm{i}}\right)}{\sum_{i=1}^{n} W_{i}}\right)
$$

Where

$\mathrm{d}_{\mathrm{gw}}$ : The geometric mean diameter, $\mathrm{mm}$.

$W_{i} \quad$ : The mass on the $i$ th sieve, g.

$n \quad$ : The number of sieves.

$d_{i} \quad$ : The nominal sieve aperture size of the $i_{\text {th }}$ sieve, $\mathrm{mm}$.

\subsubsection{Machine productivity $\left(\mathbf{P}_{\mathrm{m}}\right)$}

Time of milling process was measured by means of a stop watch. The machine productivity was calculated as follows:

$$
\mathrm{P}_{\mathrm{m}}=\frac{\mathrm{W}}{\mathrm{T}}
$$

Where

$\mathrm{P}_{\mathrm{m}} \quad$ : The machine productivity, $\mathrm{kg} \mathrm{h}^{-1}$.

$\mathrm{W}$ : The mass of sample, $\mathrm{kg}$.

$\mathrm{T}$ : Milling time, hour.

\subsubsection{Required power (RP) and consumed energy (CE)}

The required electric power under machine working load (RP) was calculated according to Chancellor (1981) by the following equation:

$$
\mathrm{RP}=\mathrm{V} \times \mathrm{I} \times \cos \theta
$$

Where

RP : The required power for crushing, W.

V : Potential difference, Voltage (I phase $=220$ voltage).

I : Line current, Amperes.

$\cos \theta \quad: \quad$ Power factor $(=0.64)$. 
A digital clamp meter and Voltmeter were used for measuring current intensity and voltage respectively.

The consumed energy (CE) is power per unit productivity; it was calculated by using the following equation:

$$
\text { Consumed energy }=\left(\mathrm{RP} / \mathrm{P}_{\mathrm{m}}\right), \quad \mathrm{W} \mathrm{h} \mathrm{kg}{ }^{-1}
$$

\subsubsection{Costs $\left(\mathrm{C}_{0}\right)$}

Machine cost was determined using the fixed costs and variable costs according to Srivastava et al. (2006), where the price of fabricated machine was 4000 L.E (according to 2017 local conditions). The operating cost $\left(\mathrm{C}_{\mathrm{O}}\right)$ was determined using the following equation:

Operating cost $(\mathrm{CO})=\frac{\text { Total machine costs }\left(\mathrm{L}^{\mathrm{E}} \mathrm{E} \mathrm{h}^{-1}\right)}{\text { Machine productivity }\left(\operatorname{ton~h}^{-1}\right)}, \mathrm{L} \cdot \mathrm{E} \mathrm{ton}^{-1}$

\section{RESULTS AND DISCUSSIONS}

\subsection{Corn kernel properties}

Table (5) reports the some physical and mechanical properties of the corn kernel.

Table (5): Physical and mechanical properties of corn kernel.

\begin{tabular}{|c|c|c|}
\hline \multicolumn{2}{|l|}{ Parameters } & Values \\
\hline \multicolumn{2}{|l|}{ Length, mm } & 11.76 \\
\hline \multicolumn{2}{|l|}{ Width, mm } & 8.76 \\
\hline \multicolumn{2}{|l|}{ Thickness, mm } & 3.96 \\
\hline \multicolumn{2}{|l|}{ Mass, $\mathbf{g}$} & 0.353 \\
\hline \multicolumn{2}{|c|}{ Bulk density, $\mathrm{kg} \mathrm{m}^{-3}$} & 1475 \\
\hline \multicolumn{2}{|c|}{ Length-to-width ratio } & 1.35 \\
\hline \multicolumn{2}{|c|}{ Perimeter length, mm } & 36.80 \\
\hline \multicolumn{2}{|c|}{ Distance between IS and CG, mm } & 1.28 \\
\hline \multicolumn{2}{|l|}{ Roundness } & 0.67 \\
\hline \multicolumn{2}{|l|}{ Area size, $\mathbf{m m}^{2}$} & 72.59 \\
\hline \multirow{3}{*}{$\begin{array}{l}\text { Rupture energy } \\
(\mathrm{RE} / \mathrm{m}), \mathrm{J} \mathrm{kg}^{-1}\end{array}$} & Longitudinal & 713.6 \\
\hline & Lateral & 359.0 \\
\hline & Diagonal & 170.7 \\
\hline
\end{tabular}




\subsection{Geometric mean diameter}

Fig. (8) illustrates the relationship between geometric mean diameter of the corn particle after ground " $d_{g w}$ " and hammer rotor speed "Rs" at different feeding rates "FR" and screen holes diameter "Sd". The obtained data showed that geometric mean diameter increased with increasing screen holes diameter and decreased with increasing both feeding rate, and hammer speed.

The geometric mean diameter ranged from 0.611 to $2.166 \mathrm{~mm}$ with hammer rotor speed of 600 to $1440 \mathrm{rpm}$, screen holes diameter of 2 to 6 $\mathrm{mm}$ and the feeding rate of 60 to $120 \mathrm{~kg} \mathrm{~h}^{-1}$. It could be noticed that the lowest values of geometric mean diameter were obtained at $\left(R_{S}\right) 1440$ $\mathrm{rpm},\left(\mathrm{S}_{\mathrm{d}}\right) 2 \mathrm{~mm}$ and $\left(F_{R}\right) 60 \mathrm{~kg} \mathrm{~h}^{-1}$, however the highest values of machine productivity were obtained at $\left(R_{S}\right) 600 \mathrm{rpm},\left(\mathrm{S}_{\mathrm{d}}\right) 6 \mathrm{~mm}$ and $\left(F_{R}\right) 120 \mathrm{~kg} \mathrm{~h}^{-}$ 1 .

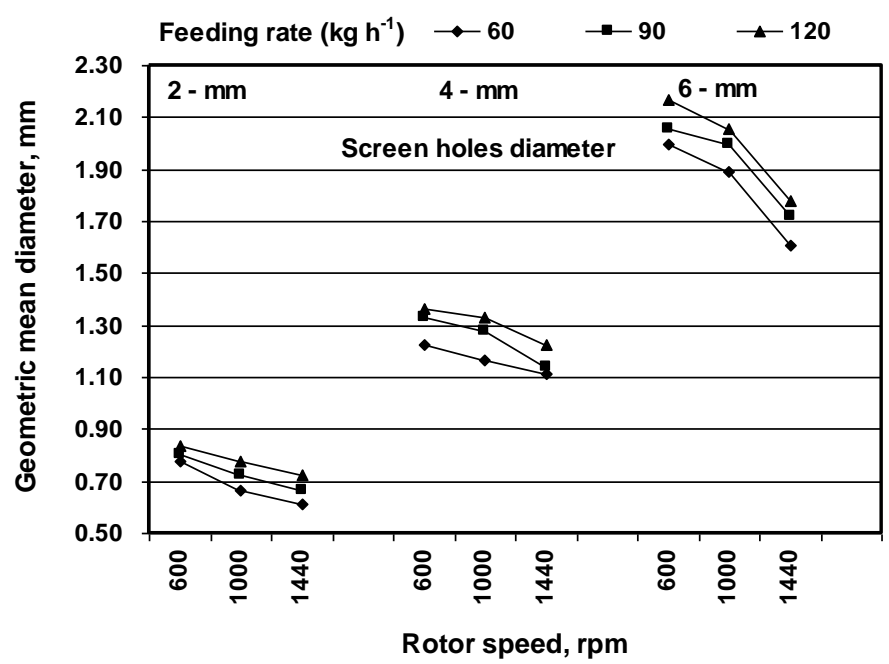

Fig. (8): The effect of hammer speed, feeding rate and screen holes diameters on grind corn geometric mean diameter.

\subsection{Machine productivity}

Fig. (9) illustrates the relationship between crushing machine productivity "Pm" and hammer rotor speed "Rs" at different feeding rates "FR" and screen holes diameter "Sd". The obtained data showed that the crushing productivity increased with increasing feeding rate, screen holes diameter and hammer speed. 
The machine productivity ranged from 30 to $112 \mathrm{~kg} \mathrm{~h}^{-1}$ with hammer rotor speed of 600 to $1440 \mathrm{rpm}$, screen holes diameter of 2 to $6 \mathrm{~mm}$ and the feeding rate of 60 to $120 \mathrm{~kg} \mathrm{~h}^{-1}$. It could be noticed that the lowest values of machine productivity were obtained at $\left(R_{S}\right) 600 \mathrm{rpm},\left(\mathrm{S}_{\mathrm{d}}\right) 2 \mathrm{~mm}$ and $\left(F_{R}\right) 60 \mathrm{~kg} \mathrm{~h}^{-1}$, however the highest values of machine productivity were obtained at $\left(R_{S}\right) 1440 \mathrm{rpm},\left(\mathrm{S}_{\mathrm{d}}\right) 6 \mathrm{~mm}$ and $\left(F_{R}\right) 120 \mathrm{~kg} \mathrm{~h}^{-1}$.

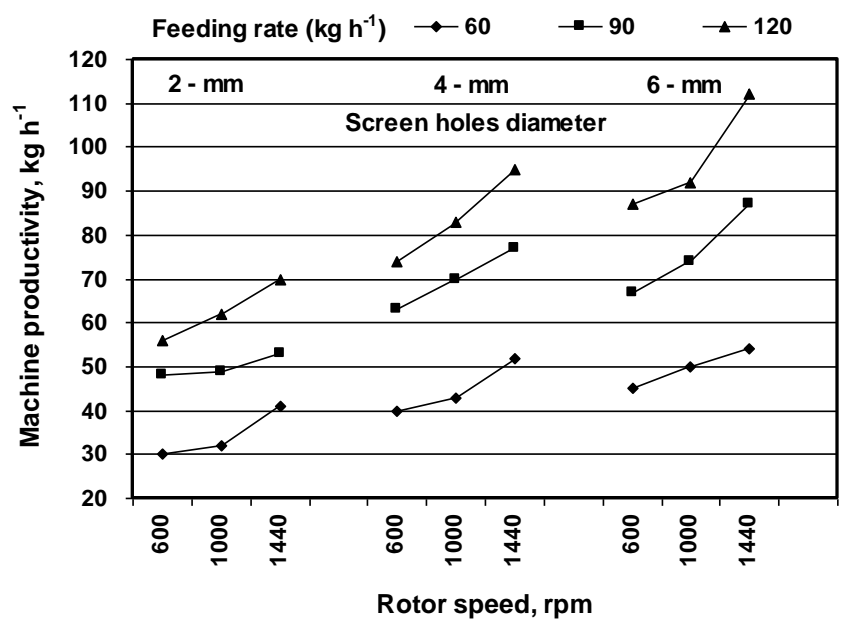

Fig. (9): The effect of hammer speed, feeding rate and screen holes diameters on machine productivity.

\subsection{Consumed energy}

Fig. (10) illustrates the relationship between consumed energy "CE" and hammer rotor speed "Rs" at different feeding rates "FR" and screen holes diameters "Sd". The obtained data showed that the consumed energy decreased with increasing feeding rate, screen holes diameter and hammer speed. The consumed energy ranged from 7.5 to $21 \mathrm{~W} . \mathrm{h} \mathrm{kg}^{-1}$ with hammer rotor speed of 600 to $1440 \mathrm{rpm}$, screen holes diameter of 2 to 6 $\mathrm{mm}$ and the feeding rate of 60 to $120 \mathrm{~kg} \mathrm{~h}^{-1}$. It could be noticed that the lowest values of consumed energy were obtained at $\left(R_{S}\right) 1440 \mathrm{rpm},\left(\mathrm{S}_{\mathrm{d}}\right) 6$ $\mathrm{mm}$ and $\left(F_{R}\right) 120 \mathrm{~kg} \mathrm{~h}^{-1}$, however the highest values of consumed energy were obtained at $\left(R_{S}\right) 600 \mathrm{rpm},\left(\mathrm{S}_{\mathrm{d}}\right) 2 \mathrm{~mm}$ and $\left(F_{R}\right) 60 \mathrm{~kg} \mathrm{~h}^{-1}$.

\subsection{Cost}

Fig. (11) illustrates the relationship between crushing machine cost " $\mathrm{C}_{\mathrm{O}}$ " and hammer rotor speed "Rs" at different feeding rates "FR" and screen holes diameters "Sd". The obtained data showed that the crushing cost 
increased with increasing of both feeding rate, screen holes diameter and hammer speed. The crushing machine cost ranged from 76 to 283.3 L.E $\mathrm{kg}$ ton $^{-1}$ with hammer rotor speed of 600 to $1440 \mathrm{rpm}$, screen holes diameter of 2 to $6 \mathrm{~mm}$ and the feeding rate of 60 to $120 \mathrm{~kg} \mathrm{~h}^{-1}$. It could be noticed that the lowest values of machine cost were obtained at $\left(R_{S}\right) 1440$ $\mathrm{rpm},\left(\mathrm{S}_{\mathrm{d}}\right) 6 \mathrm{~mm}$ and $\left(F_{R}\right) 120 \mathrm{~kg} \mathrm{~h}^{-1}$, however the highest values of machine cost were obtained at $\left(R_{S}\right) 600 \mathrm{rpm},\left(\mathrm{S}_{\mathrm{d}}\right) 2 \mathrm{~mm}$ and $\left(F_{R}\right) 60 \mathrm{~kg} \mathrm{~h}^{-}$ 1 .

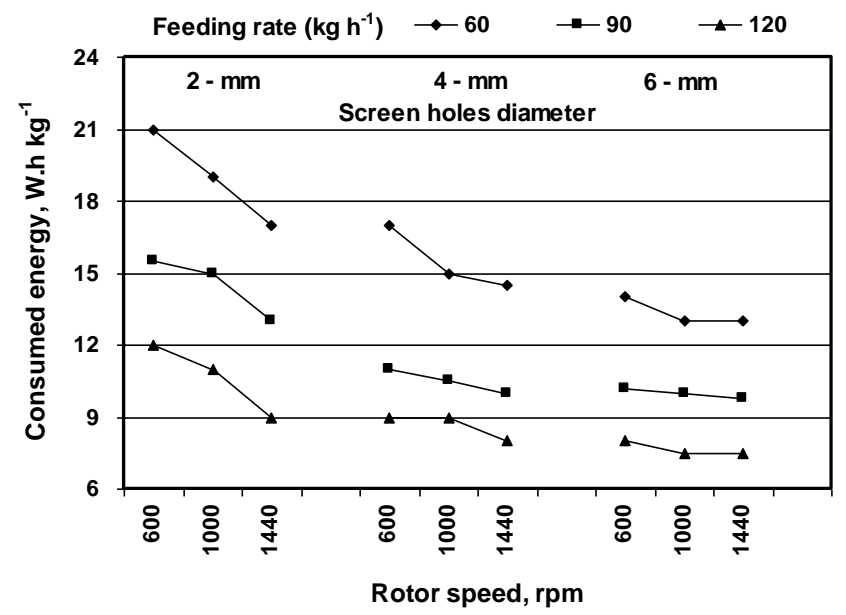

Fig. (10): The effect of hammer speed, feeding rate and screen holes diameters on machine consumed energy.

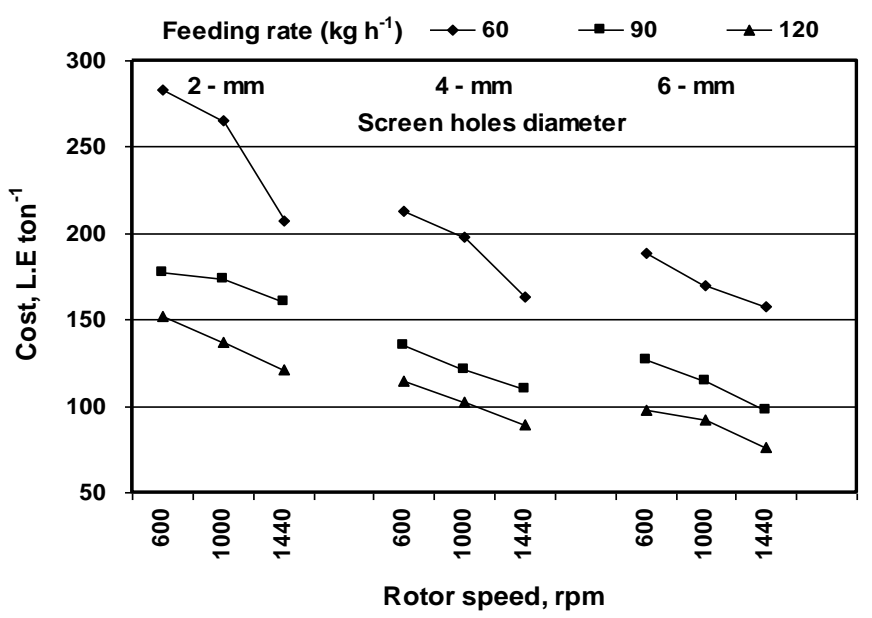

Fig. (11): The effect of hammer speed, feeding rate and screen holes diameters on machine cost. 


\subsection{Regression models for the performance parameters}

The screen holes diameter, rotor speed and feeding rate were used as factors affecting the values of geometric mean diameter, machine productivity, consumed energy and cost within their tested values. Multiple regression approach (by using SPSS software version 16) was used to derive a linear regression equation. Equation (21) expresses mathematical relation.

$$
Y=a \cdot S_{d}+b \cdot R_{S}+c \cdot F_{R}+k
$$

Where

Y

: The value of geometric mean diameter, machine productivity, consumed energy, and cost.

$\mathrm{S}_{\mathrm{d}} \quad:$ Screen holes diameter, $\mathrm{mm}\left(2 \leq \mathrm{S}_{\mathrm{d}} \leq 6\right)$.

$R_{S} \quad:$ Rotor speed, $\operatorname{rpm}\left(600 \leq R_{S} \leq 1440\right)$.

$\mathrm{F}_{\mathrm{R}} \quad:$ Feeding rate, $\mathrm{kg} \mathrm{h}^{-1}\left(60 \leq \mathrm{F}_{\mathrm{R}} \leq 120\right)$.

$\mathrm{a}, \mathrm{b}, \mathrm{c} \& \mathrm{k}$ : Empirical constants.

The values of the empirical constants ( $a, b, c$ and $k$ ) and the coefficient of determination $\left(\mathrm{R}^{2}\right)$ of equation (21) are shown in table (6).

Table (6): The empirical constants and the coefficient of determination $\left(R^{2}\right)$ for the performance parameters.

\begin{tabular}{|c|c|c|c|c|c|}
\hline \multirow{2}{*}{$(\mathbf{Y})$} & \multicolumn{4}{|c|}{ Empirical constant } & \multirow{2}{*}{$\mathbf{R}^{2}$} \\
\hline & $\mathbf{a}$ & b & $\mathbf{c}$ & $\mathbf{K}$ & \\
\hline Geometric mean diameter (dgw), mm & 0.177 & 0.297 & -0.0002 & 0.002 & 0.982 \\
\hline Machine productivity $\left(\mathrm{P}_{\mathrm{m}}\right), \mathrm{kg} \mathrm{h}^{-1}$ & 6.306 & 0.017 & 0.637 & -37.003 & 0.937 \\
\hline Consumed energy (CE), W.h kg-1 & -1.097 & -0.002 & -0.116 & 29.140 & 0.929 \\
\hline Cost $\left(\mathrm{C}_{0}\right)$, L.E ton ${ }^{-1}$ & -16.11 & -0.040 & -1.167 & 368.2 & 0.791 \\
\hline
\end{tabular}

This regression equation can be used as a guide to forecast the expected values of the studied operation parameters.

\section{CONCLUSION}

The obtained results can be summarized as follows:

1. The lowest values of geometric mean diameter were obtained at $\left(R_{S}\right)$ $1440 \mathrm{rpm},\left(\mathrm{S}_{\mathrm{d}}\right) 2 \mathrm{~mm}$ and $\left(F_{R}\right) 60 \mathrm{~kg} \mathrm{~h}^{-1}$.

2. The highest values of machine productivity were obtained at $\left(R_{S}\right)$ $1440 \mathrm{rpm},\left(\mathrm{S}_{\mathrm{d}}\right) 6 \mathrm{~mm}$ and $\left(F_{R}\right) 120 \mathrm{~kg} \mathrm{~h}^{-1}$.

3. The lowest values of consumed energy were obtained at $\left(R_{S}\right) 1440$ $\mathrm{rpm},\left(\mathrm{S}_{\mathrm{d}}\right) 6 \mathrm{~mm}$ and $\left(F_{R}\right) 120 \mathrm{~kg} \mathrm{~h}^{-1}$. 
4. The lowest values of machine cost were obtained at $\left(R_{S}\right) 1440 \mathrm{rpm}$, $\left(\mathrm{S}_{\mathrm{d}}\right) 6 \mathrm{~mm}$ and $\left(F_{R}\right) 120 \mathrm{~kg} \mathrm{~h}^{-1}$.

5. The validity of this research outcomes with different kinds of grains may be a valuable recommended for future studies.

\section{REFERENCES}

Abd El Fatah, H, E. Mohamed, M. Hassan and K. Mohamed. 2015. An economic analysis for maize market in Egypt. Middle East Journal of Agriculture Research, 4 (4): 873-878.

ASABE. 1999. Method of determining and expressing fineness of feed materials by sieving. Standard ASABE NO: S319.4. St. Joseph, Mich. ASABE: 563-566.

Berk, Z. 2018. Size reduction. Food process engineering and technology. $3^{\text {rd }}$ Edition., Academic Press: 165-191.

Bitra, V. S. P., A. R. Womac, N. Chevanan, P. I. Miu, C. Igathinathane, S. Sokhansanj and D. R. Smith. 2009. Direct mechanical energy measures of hammer mill comminution of switchgrass, wheat straw, and corn stover and analysis of their particle size distributions. Powder Technology, 193 (1): 32-45.

Bulgakov, V., S. Pascuzzi, S. Ivanovs, G. Kaletnik and V. Yanovich. 2018. Angular oscillation model to predict the performance of a vibratory ball mill for the fine grinding of grain. Biosystems Engineering, 171: 155-164.

Chancellor, W. J. 1981. Substituting information for energy in agricultural. Trans. ASAE Paper No. 0001- 2351.

CIGR. 1999. Handbook of agricultural engineering. Volume III. Plant production engineering. The International Commission of Agricultural Engineering. Published by the ASABE.

Dabbour M. I., A. Bahnasawy, S. Ali, Z. El- Haddad. 2015. Grinding parameters and their effects on the quality of corn for feed processing. J. Food Process Technol, 6:482.

El Shal, M. S., M. A. Tawfik, A. M. El Shal and K. A. Metwally. 2010. Study the effect of some operational factor on hammer mill. Misr J. Ag. Eng., 27(1): $54-74$.

Eric, O. 1976. Machinery's Hand Book. 20th ed. New York, Industrial Press. 
FAO. 2017. Food and Agricultural Organization of the United Nations, FAOSTATE data base. http://apps.fao.org/cgi-bin/nph-db.pl subset $=$ agriculture.

Han, Y., F. Jia, Y. Zeng, L. Jiang, Y. Zhang and B. Cao. 2016. Effects of rotation speed and outlet opening on particle flow in a vertical rice mill. Powder Technology, 297: 153-164.

Hannah, J. and R. Stephens. 2004. Advanced Theory and Examples in Mechanics of Machines. Edward Arnold (Publishers) Ltd, London; 5th Edition, pp.1-128.

Herrera, J., B. Saldana, L. Camara, J. D. Berrocoso and G. G. Mateos. 2018. Influence of grinding size of the main cereal of the diet on egg production and eggs quality of brown egg laying hens from 33 to 65 weeks of age. Poult. Sci., 97(7): 2506-2515.

Islam, S., M. Haque and S. Hossain. 2015. Effect of corn moisture on the Quality of Poultry Feed. Journal of Poultry Science and Technology. Vol. 3(2): 24-31.

Khurmi, R. S. and J. K.Gupta. 2005. Theory of Machines. New Delhi: Eurasia Publishing house. 315.

Leewatchararongjaroen, J. and J. Anuntagool. 2016. Effects of drymilling and wet-milling on chemical, physical and gelatinization properties of rice flour. Rice Science, 23(5): 274-281.

Mani, S., L. G. Tabil and S. Sokhansanj. 2004. Grinding performance and physical properties of wheat and barley straws, corn stover and switchgrass. Biomass and Bioenergy, 27(4): 339-352.

Parsons, S., A., N. P. Buchanan, K. P. Blemings, M. E. Wilson and J. S. Moritz. 2006. Effect of corn particle size and pellet texture on broiler performance in the growing phase. The Journal of Applied Poultry Research, 15(2): 245-255.

Pérez-Bonilla, A., M. Frikha, R. P. Lázaro and G. G. Mateos. 2014. Type of grinding of the main cereal of the diet affects production of brown egg-laying hens. Animal Feed Science and Technology, 194: 121-130.

Soyoye, B. O., O. C. Ademosun, and L. A. S. Agbetoye. 2018. Determination of some physical and mechanical properties of 
soybean and maize in relation to planter design. Agricultural Engineering International: CIGR Journal, 20(1): 81-89.

Srivastava, A. K., C. E. Goering, R. P. Rohrbach and D. R. Buckmaster. 2006. Engineering principles of agricultural machines. $2^{\text {nd }}$ ed. St. Joseph, Michigan: ASABE.

Tanabata, T., T. Shibaya, K. Hori, K. Ebana and M. Yano. 2012. High throughput phenotyping software for measuring seed shape through Image Analysis. Plant Physiology, 160 (4): 1871-1880.

Tumuluru, J. S., L. G. Tabil, Y. Song, K. L. Iroba and V. Meda. 2014. Grinding energy and physical properties of chopped and hammer milled barley, wheat, oat and canola straws. Biomass and Bioenergy, 60: 58-67.

Verheye, W. 2010. Growth and production of maize: traditional lowinput cultivation. In: Verheye, W. (ed.), Land Use, Land Cover and Soil Sciences. Encyclopedia of Life Support Systems (EOLSS), UNESCO-EOLSS Publishers, Oxford, UK. http://www.eolss.net.

Wołosiewicz-Głąb, M., D. Foszcz and S. Ogonowski. 2017. Design of the electromagnetic mill and the air stream ratio model. IFACPapers On Line, 50(1): 14964-14969.

Yousef, I. S. 2005. A study on performance improvement of the local manufactured hammer mill used in poultry forms. J. Agric., Sci. Mansoura Univ., 30 (11): 6827-6840.

Zohry, A., S. Ouda and T. Noreldin. 2016. Solutions for maize production-consumption gap in Egypt. Conference: 4th African Regional Conferences on Irrigation and Drainage (ARCID) Aswan, Egypt.

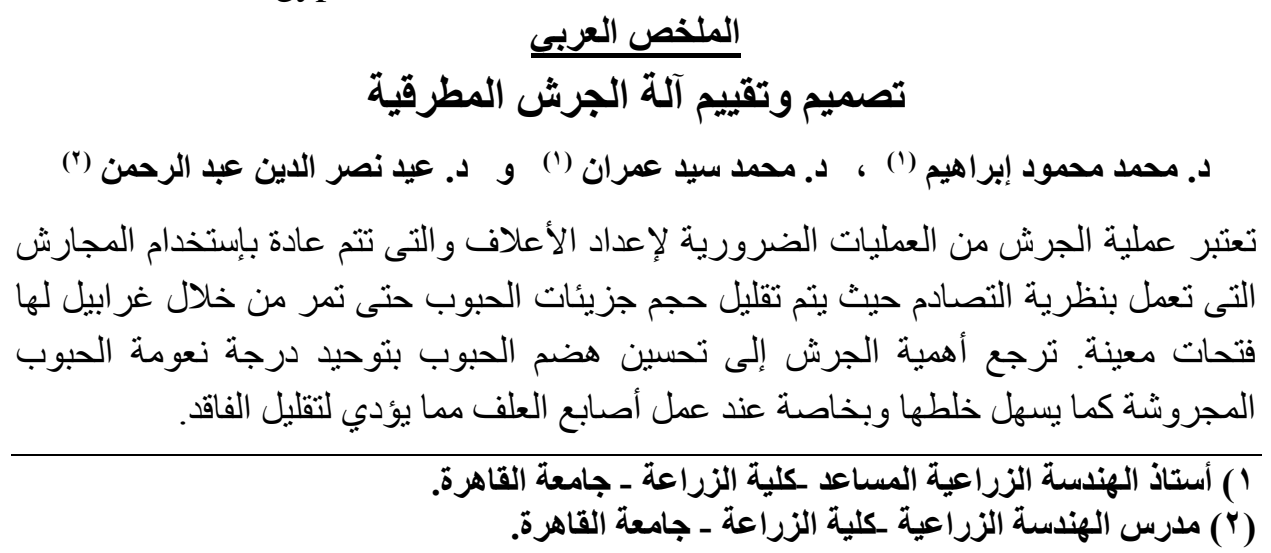


وتهدف هذه الدراسة إلى تصميم وتصنيع وتقييم آلة جرش صغيرة الحجم. وللوصول للهدف تم الاتى:

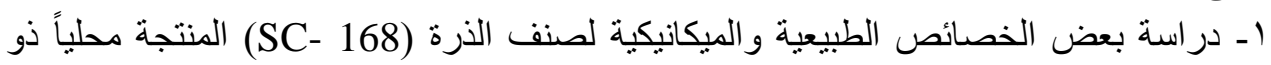

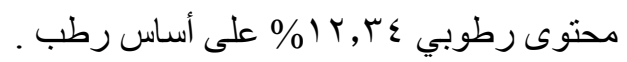

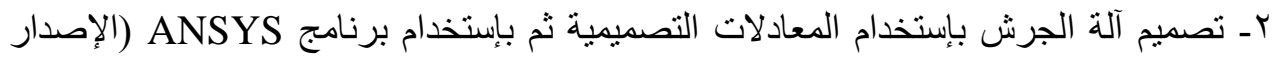

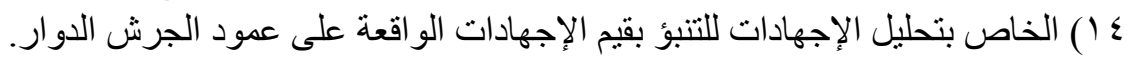

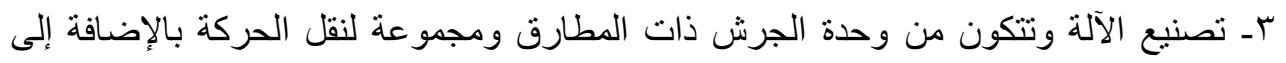

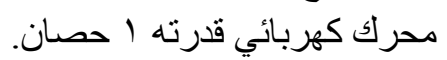

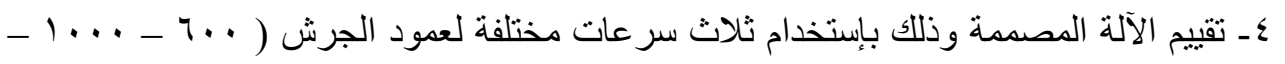

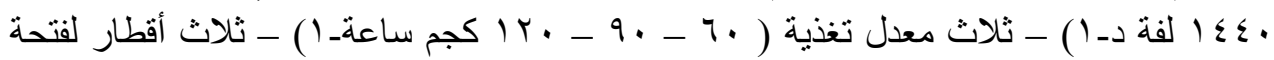

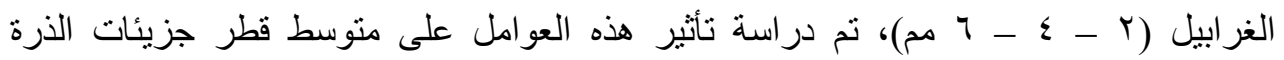
المجروشة، السعة الإنتاجية للآلة، الطاقة المستهلكة أثناء الجرش، الثرة تكلفة عملية الجرش. توصلت الدراسة لأهم النتائج التالية:

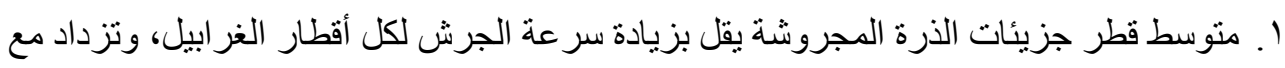

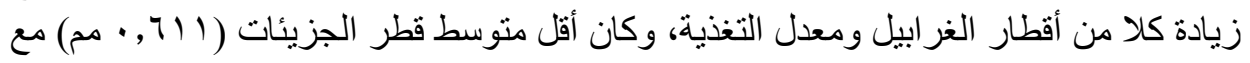

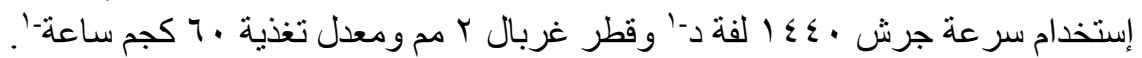

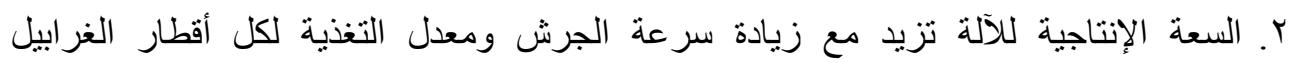

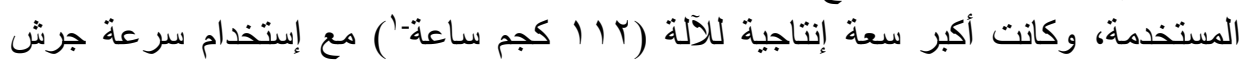

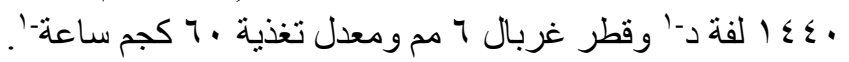

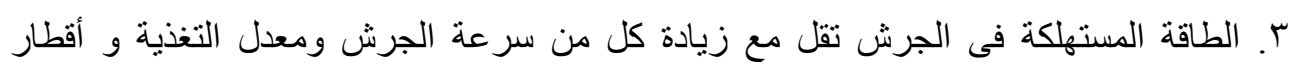

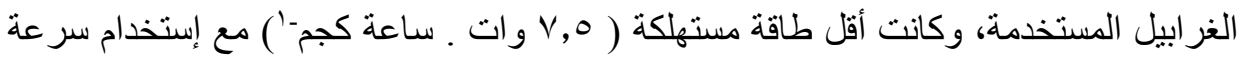

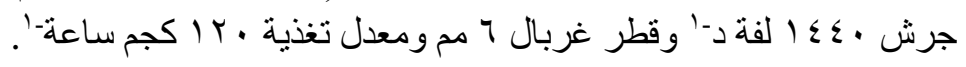

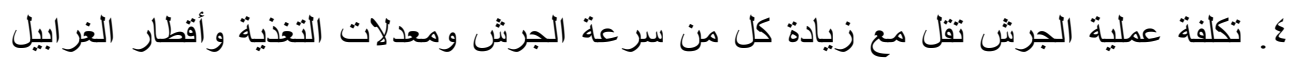

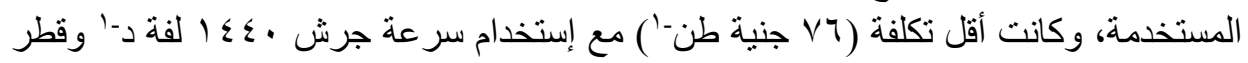

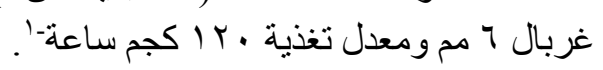

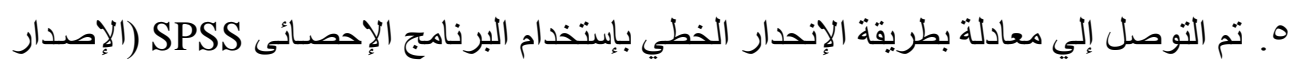

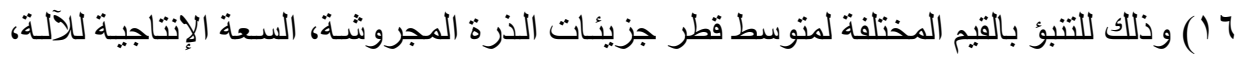
الطاقة المستهلكة، تكلفة عملية الجرش كدالة فى سر عة الجرش ومعدل التخذية وقطر الغر ابيل.

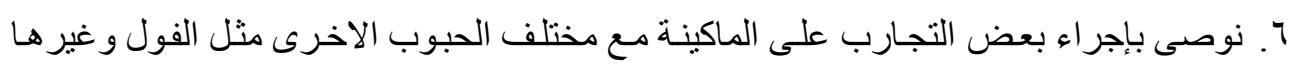
التى تستخدم مع الأعلاف. 